\title{
The Transition of Iowa from Territory to State ${ }^{1}$
}

\author{
By Wm. H. Fleming
}

The territory of Iowa was only about a year old when talk of statehood began to be indulged in. In his message to the Second legislative assembly, Governor Robert Lucas recommended that congress be memorialized to pass a bill authorizing the people of the territory to form a constitution and state government, and to provide for the state's admission into the Union. He went on to point out what he thought "the most natural boundaries for our state."

The following summer the legislature provided for submitting to the people the question of holding a convention to draft a constitution for the government of the proposed state. The people then (1840) voted down the project by a decided majority.

When the Fourth legislative assembly met (1841), Governor John Chambers expressed the opinion that there had been a sufficient change in the popular sentiment to warrant a resubmission of the question to the

1 An informative excerpt from a manuscript in the archives of the Iowa State Department of History and Archives. The author, William Henry Fleming, was born in New York City April 14, 1833, and died in Des Moines, Iowa, October 14, 1923. In 1847, he began as an apprentice in the printing trade in the office of the Christian Intelligencer in New York City. In 1854, he removed to Davenport, Iowa, and for several years worked on papers there, principally the Davenport Gazette, eventually becoming city editor. Some time during the Civil war he was employed by Adjutant General N. B. Baker in his office in Clinton. He removed to Des Moines in 1867 and became private secretary to Governor Samuel Merrill. He acted in that capacity not only for Merrill but also for Governors Kirkwood, Newbold; Gear, Drake and Shaw. At intervals he became deputy state auditor, did much other special work about the state house, holding official positions with several general assemblies, and did newspaper and historical writing. From 1902 to 1907 , he held a position in the United States Treasury Department under Secretary L. M. Shaw, after which service he was upon the staff in the Iowa State Historical Department at Des Moines, and served as secretary of the Pioneer Lawmakers Association of Iowa.-Editor. 
people. ${ }^{2}$. This was accordingly done, and with the same result-every county in the territory giving a majority in the negative. This was in 1842.

The governor was still urgent for admission, and he recommended in his message of December, 1843, that the question be again voted on, and that congress be asked to establish a boundary for the state, and to sanction the holding of a constitutional convention. The legislature passed the bill for taking the popular vote, which was done in 1844, and this time the friends of statehood were successful.

A convention was chosen consisting of seventy members. Among them were ex-Governor Lucas, James Clarke, who was afterwards governor of the territory, Ralph P. Lowe, destined to be governor of the state and judge of its district and supreme courts; Elisha Cutler, Jr., of Van Buren, and Elijah Sells of Muscatine county, afterwards secretaries of the state; Jonathan. C. Hall, also a judge of the state supreme court; James Grant, long prominent at the bar and speaker in the Fourth general assembly; Stephen B. Shelledy, speaker in the Seventh; Thomas J. McKean, a graduate of the military academy, and one of the leaders of the Whig party; besides others more or less prominent in later days. Of all the members of that convention, it is believed that only Gideon S. Bailey of Van Buren county, who is also the last survivor of the First legislative assembly, is living at this writing.

2 Both Governor Lucas and Governor Chambers of Iowa Territory recommended that statehood be attained. Lucas suggested boundaries similar to those of the present state. Vote of April 1, 1844, in the territory favored holding a constitutional convention with 6,719 for and 3,074 against. The convention opened October 7 following, adopted a proposed constitution with boundaries of state to be substantially as recommended by Governor Lucas and adjourned November 1. The proposed constitution was presented in congress December 9 for the large state, but a congressional committee recommended a reduced area, the western limits to extend only to west side of what is now Dallas county, though did include two tiers of counties now a part of Minnesota, which bill passed congress, but the small-state area was rejected by Iowa voters April 7, 1845. Insistancel by the people of Iowa upon the large-state boundaries resulted in congress finally accepting same, and the new state of Iowa was admitted to the Union upon signing of the act of congress by. Pres. James K. Polk on December 28, 1846.-Editor. 
It was this convention that adopted the boundaries recommended by Governor Lucas. The constitution formulated by it had a stringent clause providing that stockholders in all corporations should be individually liable for all the debts of the same. It had a provision also that would have made it difficult to construct railroads or telegraph or telephone lines unless by the state. That provision forbade the taking of private property by any corporation other than a municipality. The proposed constitution was not, however, as severe on banking as was the one under which the state entered the Union. The latter entirely prohibited banks. The former permitted the chartering of banks, but the charters must be approved by popular vote. The capital was to remain at Iowa City until 1865 , and until removed by law.

On the 9th of December, 1844, the proposed constitution was presented in the senate of the United States by Benjamin Tappan of Ohio. Three days afterwards Delegate A. C. Dodge submitted it in the house. A brief partisan debate followed on the question of reference-the Whigs wanting it to go to the judiciary committee, while the Democrats would send it to the committee on territories, whither it went.

\section{COUPLED IOWA AND Florma}

On January 7, 1845, Aaron V. Brown of Tennessee, presented from the committee on territories a bill for the admission of Iowa and Florida into the Union. Provision was made for dividing the latter into two states in process of time, notwithstanding the fact that the whole peninsula hadn't then more than about one-fourth as much population as had Iowa. The object was to make provision for "preserving the balance" between the free and the slave states, a favorite idea with the temporizing statesmen of the time.

During the discussion on the bill, Alexander Duncan, an Ohio Democrat, moved to make the northern and western lines of the state to run respectively 
east and west from a point at the junction of the Blue Earth and St. Peters, or Minnesota river, being about two miles from where the town of Mankato now stands. Dr. Duncan said in defense of his proposition that the boundaries proposed by him comprised an area that contained double and treble the amount of "valuable land" to be found in either Missouri or Virginia. He introduced a statement of the topographical engineer, stating that the boundaries he proposed inclosed an area as large as Ohio or New York, and "larger in point of fertility of soil than any two states in the United States."

Samuel F. Vinton, a leading Whig from Ohio, supported the amendment urging that there ought to be smaller states in the west, where, he said, the spirit of disunion would never live, and which section, he said, would hold the Union together. The amendment was adopted, and the bill was further amended by striking out the provision for two states in Florida.

A spicy debate sprang up on a motion by a Maine man to compel the amendment of the Florida constitution by striking therefrom a clause prohibiting emancipation, and another empowering the legislature to prohibit free negroes from coming into the state, and their being discharged from vessels in the ports of Florida. A Georgian met the suggestion with an amendment to strike from the Iowa constitution its prohibition of slavery. Both amendments were voted down, and the bill was passed 145 to 45 . Most of the negative votes were cast by northern Whigs whose opposition was mainly occasioned by the coupling of Florida with Iowa.

In the senate, the Whig majority sent the bill to the judiciary committee February 24. John M. Berrien, senator from Georgia, reported the bill from that committee. On the 1st of March, it was taken up for consideration. The debate here turned entirely upon the Florida constitution. The leading northern Whigs opposed the passage of the bill in the shape in which 
it was presented. Rufus Choate said the joint legislation by which it was sought to bring the two states in together was of an extraordinary character. It had never been done before. It was a great injustice to him and his friends to be compelled to vote against the bill. They could not conscientiously sanction what they could not approve in one of the constitutions now presented, although they would gladly open their arms to receive the other state into the family embrace.

An attempt to strike from the Florida constitution the offensive clauses received the support of only 12 senators, all northern Whigs, while 11 Whigs and 24 Democrats voted against it. The bill then passed by 35 to 9 , the latter all northern Whigs. It received the signature of John Tyler March 4.

\section{Iowans Opposed Smaller Area}

In the month of April the people of Iowa rejected the constitution with the area limits set by congress. The Seventh territorial legislature provided for a vote upon the constitution as it came from the hands of the convention. The vote was again unfavorable, the friends of the measure numbering only 7,235 against 7,656 .

Thus matters stood for several months. Meantime, it was proposed to make the forty-second parallel the northern boundary, which would have given the state an area about the same as that of Indiana and a shape like that of Tennessee. North of the new state was planned a territory to be called "Dakota."

Early in 1846, Delegate Dodge introduced a bill to define the boundaries of Iowa. March 27, 1846, Stephen A. Douglas reported the bill from the committee on territories, with an amendment fixing the boundaries as they are now. Julius Rockwell of Massachusetts proposed the forty-second parallel for the northern boundary. Douglas said that was a scheme of Dubuque people to make their town the largest in a new state. Rockwell said that he agreed with the people of Dubuque when they said that the lines pro- 
posed for Iowa would not leave room enough for another state on the Mississippi river; Vinton preferred the boundaries which the people rejected. He was led to believe that no part of the United States possessed an equal capacity for maintaining an immense population. It was certainly equal to, if not greater than, that of any other part of the West. In addition, Iowa enjoyed hydraulic facilities equal to those of any other state.

The bill passed the house in the month of June. August 1 it passed the senate without opposition. It was signed by the president August 4, just one day after the people had adopted the new constitution, in which the boundaries were described à in the act of congress. The popular vote was 9,492 against 9,036.

December 16, Delegate Dodge laid the new constitution before the house. December 17, Douglas, from the committee on territories, introduced a bill for admission of Iowa: Four days later the bill passed the house. The senate passed it December 24 and it was signed by the president four days later. Next day, December 29, Shepherd Leffler and Serranus Clinton Hastings presented their credentials as representatives and took the oath of office and their seats. No senators appeared for two years, owing to the inability of the two houses of the Iowa legislature to agree on a time to hold the election for senators, after one abortive meeting had been held.

\section{Seek Co-operation First}

There is a point, of course, where a man must take the isolated peak and break with all his associates for clear principle; but until that time comes he must work, if he would be of use, with men as they are. As long as the good in them overbalances the evil, let him work with them for the best that can be obtained.-THEODORE ROOSEVELT. 
Copyright of Annals of Iowa is the property of State of Iowa, by \& through the State Historical Society of Iowa and its content may not be copied or emailed to multiple sites or posted to a listserv without the copyright holder's express written permission. However, users may print, download, or email articles for individual use. 